\title{
Review Article \\ Chromium as an Environmental Pollutant: Insights on Induced Plant Toxicity
}

\author{
Helena Oliveira \\ Department of Biology, CESAM, University of Aveiro, 3810-193 Aveiro, Portugal \\ Correspondence should be addressed to Helena Oliveira, holiveira@ua.pt \\ Received 23 November 2011; Revised 15 March 2012; Accepted 16 March 2012 \\ Academic Editor: Joanna Deckert
}

Copyright (C) 2012 Helena Oliveira. This is an open access article distributed under the Creative Commons Attribution License, which permits unrestricted use, distribution, and reproduction in any medium, provided the original work is properly cited.

In the past decades the increased use of chromium $(\mathrm{Cr})$ in several anthropogenic activities and consequent contamination of soil and water have become an increasing concern. Cr exists in several oxidation states but the most stable and common forms are $\mathrm{Cr}(0), \mathrm{Cr}(\mathrm{III})$ and $\mathrm{Cr}(\mathrm{VI})$ species. Cr toxicity in plants depends on its valence state. $\mathrm{Cr}(\mathrm{VI})$ as being highly mobile is toxic, while $\mathrm{Cr}$ (III) as less mobile is less toxic. $\mathrm{Cr}$ is taken up by plants through carriers of essential ions such as sulphate. Cr uptake, translocation, and accumulation depend on its speciation, which also conditions its toxicity to plants. Symptoms of Cr toxicity in plants are diverse and include decrease of seed germination, reduction of growth, decrease of yield, inhibition of enzymatic activities, impairment of photosynthesis, nutrient and oxidative imbalances, and mutagenesis.

\section{Introduction}

Chromium (Cr) is the 17th most abundant element in the Earth's mantle [1]. It occurs naturally as chromite $\left(\mathrm{FeCr}_{2} \mathrm{O}_{4}\right)$ in ultramafic and serpentine rocks or complexed with other metals like crocoite $\left(\mathrm{PbCrO}_{4}\right)$, bentorite $\mathrm{Ca}_{6}(\mathrm{Cr}, \mathrm{Al})_{2}\left(\mathrm{SO}_{4}\right)_{3}$ and tarapacaite $\left(\mathrm{K}_{2} \mathrm{CrO}_{4}\right)$, vauquelinite $\left(\mathrm{CuPb}_{2} \mathrm{CrO}_{4} \mathrm{PO}_{4} \mathrm{OH}\right)$, among others [2]. $\mathrm{Cr}$ is widely used in industry as plating, alloying, tanning of animal hides, inhibition of water corrosion, textile dyes and mordants, pigments, ceramic glazes, refractory bricks, and pressure-treated lumber [1]. Due to this wide anthropogenic use of $\mathrm{Cr}$, the consequent environmental contamination increased and has become an increasing concern in the last years [3].

Chromium exists in several oxidation states, but the most stable and common forms are $\operatorname{Cr}(0)$, the trivalent $\mathrm{Cr}(\mathrm{III})$, and the hexavalent $\mathrm{Cr}(\mathrm{VI})$ species. $\mathrm{Cr}(0)$ is the metallic form, produced in industry and is a solid with high fusion point usually used for the manufacturing of steel and other alloys. $\mathrm{Cr}(\mathrm{VI})$ in the forms of chromate $\left(\mathrm{CrO}_{4}{ }^{2-}\right)$, dichromate $\left(\mathrm{CrO}_{4}{ }^{2-}\right)$, and $\mathrm{CrO}_{3}$ is considered the most toxic forms of chromium, as it presents high oxidizing potential, high solubility, and mobility across the membranes in living organisms and in the environment. Cr(III) in the forms of oxides, hydroxides, and sulphates is less toxic as it is relatively insoluble in water, presents lower mobility, and is mainly bound to organic matter in soil and aquatic environments. Moreover, $\mathrm{Cr}$ (III) forms tend to form hydroxide precipitates with $\mathrm{Fe}$ at typical ground water $\mathrm{pH}$ values. At high concentrations of oxygen or Mn oxides, $\mathrm{Cr}$ (III) can be oxidized to $\mathrm{Cr}(\mathrm{VI})[4,5]$.

As $\mathrm{Cr}(\mathrm{VI})$ and $\mathrm{Cr}(\mathrm{III})$ present different chemical, toxicological, and epidemiological characteristics, they are differently regulated by EPA, which constitutes a unique characteristic of $\mathrm{Cr}$ among the toxic metals [6]. $\mathrm{Cr}(\mathrm{VI})$ is a powerful epithelial irritant and also considered a human carcinogen [7]. $\mathrm{Cr}(\mathrm{VI})$ is also toxic to many plants [8] aquatic animals [9], and microorganisms [10]. Contrarily to $\mathrm{Cr}(\mathrm{VI}), \mathrm{Cr}(\mathrm{III})$ is considered a micronutrient in humans, being necessary for sugar and lipid metabolism [11] and is generally not harmful. In plants, particularly crops, $\mathrm{Cr}$ at low concentrations (0.05$1 \mathrm{mg} \mathrm{L}^{-1}$ ) was found to promote growth and increase yield, but it is not considered essential to plants $[5,12]$. In this context, accumulation of chromium in edible plants may represent a potential hazard to animals and humans.

\section{Chromium in the Environment}

2.1. Chromium in Water. Chromium may enter the natural waters by weathering of $\mathrm{Cr}$-containing rocks, direct discharge 
from industrial operations, leaching of soils, among others. In the aquatic environment $\mathrm{Cr}$ may suffer reduction, oxidation, sorption, desorption, dissolution, and precipitation [6].

The aqueous solubility of $\mathrm{Cr}$ (III) is a function of the $\mathrm{pH}$ of the water. Under neutral to basic $\mathrm{pH}, \mathrm{Cr}$ (III) will precipitate and conversely under acidic $\mathrm{pH}$ it will tend to solubilize. The forms of $\mathrm{Cr}(\mathrm{VI})$ chromate and dichromate are extremely soluble under all $\mathrm{pH}$ conditions, but they can precipitate with divalent cations [6]. The recommended limits for $\mathrm{Cr}$ concentration in water are $8 \mu \mathrm{g} \mathrm{L} \mathrm{L}^{-1}$ for $\mathrm{Cr}$ (III) and $1 \mu \mathrm{g} \mathrm{L}^{-1}$ for $\mathrm{Cr}(\mathrm{VI})$. In the effluents in the vicinity of $\mathrm{Cr}$ industries the levels of Cr range from 2 to $5 \mathrm{~g} \mathrm{~L}^{-1}$ [13].

2.2. Chromium in Soil. The concentration of $\mathrm{Cr}$ in the soils may vary considerably according to the natural composition of rocks and sediments that compose them [6]. The levels of chromium in the soil may increase mainly through anthropogenic deposition, as for example atmospheric deposition [14], also dumping of chromium-bearing liquids and solid wastes as chromium byproducts, ferrochromium slag, or chromium plating baths [6]. Generally, $\mathrm{Cr}$ in soil represents a combination of both $\mathrm{Cr}$ (III) and (VI). As in aquatic environment, once in the soil or sediment, $\mathrm{Cr}$ undergoes a variety of transformations, such as oxidation, reduction, sorption, precipitation, and dissolution [6]. The oxidants present in the soil (e.g., dissolved oxygen and $\mathrm{MnO}_{2}$ ) can oxidize $\mathrm{Cr}$ (III) to $\mathrm{Cr}$ (VI) [15]; however, it seems that oxidation of $\mathrm{Cr}$ (III) by dissolved $\mathrm{O}_{2}$ is residual when compared with $\mathrm{MnO}_{2}$. The forms of $\mathrm{Cr}(\mathrm{VI})$ are on the other hand reduced by iron, vanadium, sulphydes, and organic materials [16]. However, when the reducing capacity of the soil is overcome, $\mathrm{Cr}$ (VI) may persist in the soil or sediment for years, especially if the soils are sandy or present low levels of organic matter.

López-Luna et al. [17] compared the toxicity of $\mathrm{Cr}(\mathrm{VI})$, $\mathrm{Cr}$ (III), and Cr tannery sludge respecting to $\mathrm{Cr}$ mobility in the soil and toxicity in wheat, oat, and sorghum plants and found that $\mathrm{Cr}$ (VI) was more mobile in soil and caused higher toxicity on those plant seedlings, while tannery sludge was the least toxic [17].

\section{Chromium in Plants}

3.1. Chromium Uptake. The pathway of Cr uptake in plants is not yet clearly elucidated. However, being a nonessential element, $\mathrm{Cr}$ does not have any specific mechanism for its uptake and is also dependent on Cr speciation. Plant uptake of $\mathrm{Cr}$ (III) is a passive process, that is, no energy expenditure is required by the plant $[3,18]$. The uptake of $\mathrm{Cr}(\mathrm{VI})$ is thought to be an active mechanism performed by carriers for the uptake of essential elements such as sulphate $[19,20]$. Cr also competes with $\mathrm{Fe}, \mathrm{S}$, and $\mathrm{P}$ for carrier binding [8].

$\mathrm{Cr}(\mathrm{VI})$ has higher solubility and thus bioavailability is more toxic at lower concentrations than $\mathrm{Cr}$ (III), which tends to form stable complexes in the soil [17]. There are conflicting results concerning the uptake and translocation of $\mathrm{Cr}(\mathrm{VI})$. While some authors defend that $\mathrm{Cr}(\mathrm{VI})$ is reduced to $\mathrm{Cr}$ (III) on the root surface $[21,22]$, others suggest that dissolved $\mathrm{Cr}(\mathrm{VI})$ is taken up by plants without reduction [23].
Thus, Cr toxicity is dependent on metal speciation, which is determinant for its uptake, translocation, accumulation. $\mathrm{Cr}$ is toxic for agronomic plants at about 0.5 to $5.0 \mathrm{mgm} \mathrm{L}^{-1}$ in nutrient solution and 5 to $100 \mathrm{mg} \mathrm{g}^{-1}$ in soil [24]. Under normal conditions, concentration of $\mathrm{Cr}$ in plants is less than $1 \mu \mathrm{gg}^{-1}[25]$.

3.2. Chromium Accumulation and Translocation. Cr accumulates mainly in roots and shoots; however roots accumulate the major part, being usually only a small part translocated to the shoots $[12,26]$. In pea plants exposed to $\mathrm{Cr}$ there was an increase in concentration of $\mathrm{Cr}$ in different parts of the plant with the increase of Cr supply. Accumulation of $\mathrm{Cr}$ in the different parts of the plant was in the following order roots $>$ stem $>$ leaves $>$ seed [27]. Corroborating these results are the findings of several works and for instance, Huffman and Allaway [28] found that bean seeds accumulated about $0.1 \% \mathrm{Cr}$, while roots accumulated 98\%. Furthermore, Liu and coworkers [29] studied hydroponically grown A. viridis L. under different concentrations of $\mathrm{Cr}(\mathrm{VI})$ and found that $\mathrm{Cr}$ was accumulated primarily in roots [29]. Another study performed by Vernay et al. [30] in Lolium perenne grown in the presence of $500 \mu \mathrm{M}$ of $\mathrm{Cr}(\mathrm{VI})$ showed that roots accumulated 10 times more $\mathrm{Cr}$ than leaves. Spinach (Spinacia oleracea L. cv. "Banarasi") grown in the presence of $\mathrm{Cr}(\mathrm{VI})$ showed more accumulation of $\mathrm{Cr}$ in the roots than in leaves and stem showed the least accumulation [31]. Also, in celery seedlings grown in the presence of C(III) most $\mathrm{Cr}$ was accumulated in roots [32].

López-Luna and coworkers [17] found that roots of wheat, oat, and sorghum accumulated more Cr than shoots; however in spite of that, wheat, oat, and sorghum showed $\mathrm{Cr}$ translocation from roots to shoots. Furthermore, Zayed et al. [33] tested $\mathrm{Cr}(\mathrm{III})$ and $\mathrm{Cr}(\mathrm{VI})$ translocation in several crops and found that translocation of both $\mathrm{Cr}$ forms from roots to shoots was very low and accumulation of $\mathrm{Cr}$ by roots was 100-fold higher than in shoots, despite of the $\mathrm{Cr}$ species. However, Skeffington and coworkers [18] found that more 51Cr was transported from root to shoot when $\mathrm{Cr}(\mathrm{VI})$, rather than $\mathrm{Cr}(\mathrm{III})$, was supplied to the plant. At high $\mathrm{Cr}$ doses $\left(1 \mathrm{mM} \mathrm{CrCl}_{3}\right)$ roots accumulated very high levels of $\mathrm{Cr}$ and translocation was mainly to cotyledonary leaves and only small amounts in hypocotyls. Chatterjee and Chatterjee [34] also found low levels of translocation of Cr from roots to the shoots in cauliflower (Brassica oleracea) grown on sand with $0.5 \mathrm{mM} \mathrm{Cr}$ (III).

These results may conclude that $\mathrm{Cr}$ is mainly accumulated in roots, followed by stems and leaves; however only small amounts of $\mathrm{Cr}$ are translocated to leaves. This pattern seems independent of the form of Cr tested.

\subsection{Plants with Potential of Phytoremediation of Chromium} Contamination. In phytoremediation, hyperaccumulator plants are used to extract and transform toxic metals, as $\mathrm{Cr}$, into nontoxic and immobile compounds [35]. Cr hyperaccumulator plants can accumulate $>1,000 \mathrm{mg} \mathrm{Cr} \mathrm{kg}^{-1}$ (DW), in plant leaves. These plants can tolerate metals through 
chelation with appropriate high-affinity ligands, biotransformation with reductants, and compartmentalization in the cytoplasm or in the vacuole. Thus, Cr immobilization in vacuoles in plant root cells may represent an important mechanism of Cr detoxification by the plant $[8,36]$.

The bioconcentration factor (BCF) and translocation factor (TF) are usually used to evaluate plant ability to tolerate and accumulate heavy metals. The BCF is the ratio of metal concentration in the plant tissue to the soil and TF is the ratio of metal concentration in plant shoots to the roots. Plants exhibiting a shoot BCF $>1$ are suitable for phytoextraction, and plants with a root $\mathrm{BCF}>1$ and $\mathrm{TF}<1$ have the potential for phytostabilization [37].

Rafati and coworkers [37] evaluated the ability to uptake $\mathrm{Cr}$ from the soil by different organs of Populous alba and Morus alba. Leaves accumulated higher levels of $\mathrm{Cr}$ than stems or roots. However, neither $P$. alba nor M. alba showed potential of $\mathrm{Cr}$ phytostabilization, since presented TF $>1$ and root $\mathrm{BCF}<1$; also these plants are not suitable for phytoextraction as they presented a $\mathrm{BCF}<1$. In another study, Gafoori and coworkers [38] evaluated the potential accumulation of heavy metals, including $\mathrm{Cr}$ in Dyera costulata. This specie presented high potential to retain high amounts of $\mathrm{Cr}$ in leaves, suggesting that this specie has high phytoremediation potential, as presented high translocation factor and low BCF factor. Pluchea indica also shown a good potential of phytoremediation, as it presented high levels of $\mathrm{Cr}$ accumulation and translocation to the leaves [39]. Mellem and coworkers [40] found that Amaranthus dubius tolerate high $\mathrm{Cr}(\mathrm{VI})$ concentrations as indicated by the BCF value $>2$, showing good potential for phytoremediation. Furthermore, Gardea-Torresdey and coworkers [41] found that Convolvulus arvensis L. exposed to $20 \mathrm{mg} \mathrm{L}^{-1}$ of $\mathrm{Cr}(\mathrm{VI})$ demonstrated capability to accumulate more than $3800 \mathrm{mg}$ of $\mathrm{Cr} \mathrm{kg}^{-1} \mathrm{dw}$ tissue, showing that this specie can be used in phytoremediation of $\mathrm{Cr}(\mathrm{VI})$ contaminated soils. Also, the concentration of $\mathrm{Cr}$ in leaf tissue $\left(2100 \mathrm{mg} \mathrm{kg}^{-1} \mathrm{dw}\right)$ indicates that this plant species could be considered as a potential Cr-hyperaccumulator.

Ipomoea aquatica is a chromium hyperaccumulator that shows no toxicity symptoms when exposed to high levels of $\mathrm{Cr}(\mathrm{VI})$. Up to $28 \mathrm{mg} \mathrm{L}^{-1} \mathrm{Cr}(\mathrm{VI})$, I. aquatica exhibits uniform absorption characteristics showing over $75 \%$ removal of added $\mathrm{Cr}(\mathrm{VI})$. Over $90 \% \mathrm{Cr}(\mathrm{VI})$ is accumulated in stems and leaves, that is, aerial regions [42]. Furthermore, Mant and coworkers [43] found that Pennisetum purpureum and Brachiaria decumbens exposed to $20 \mathrm{mg} \mathrm{L}^{-1}$ of $\mathrm{Cr}$ (III) showed a metal removal efficiency of $78 \%$ and $66 \%$. Also, Barbosa and coworkers [44] found that Genipa americana has potential for $\mathrm{Cr}$ (III) phytoremediation in contaminated watersheds, since its seedlings uptake elevated amounts of $\mathrm{Cr}$ (III) from the solution and it presented high capacity of immobilizing and storing the metal on their roots.

\subsection{Growth and Development}

3.4.1. Germination. The presence of $\mathrm{Cr}$ in the medium may compromise several processes in plants, as for instance plant germination. Thus, the ability to germinate in the presence of Cr may indicate the degree of tolerance to $\mathrm{Cr}$ [45]. Oat seed germination was severely diminished $(84 \%$, resp. to the control) in tannery sludge soil with $4000 \mathrm{mg} \mathrm{Cr} \mathrm{kg}^{-1}$, while in tannery sludge soil containing $8000 \mathrm{mg} \mathrm{Cr} \mathrm{kg}^{-1}$ both oat and sorghum seed germination was suppressed [17]. When comparing the sensitivity of sorghum, wheat, and oat germination to Cr, López-Luna and coworkers found that germination of sorghum and wheat were markedly affected at $500-1000 \mathrm{mg} \mathrm{Cr}(\mathrm{III}) \mathrm{kg}^{-1}$ soil respectively, while oat germination was not affected in levels of $\mathrm{Cr}$ (III) below $4000 \mathrm{mg} \mathrm{kg}^{-1}$ soil [17]. With respect to to $\mathrm{Cr}(\mathrm{VI})$ it affected wheat and sorghum germination at the maximum concentration of $500 \mathrm{mg} \mathrm{kg}^{-1}$ soil [17]. Germination of $T$. aestivum seeds was also affected by exposure to $100 \mathrm{mg} \mathrm{L}^{-1}$ of $\mathrm{Cr}(\mathrm{VI})$ [46]. Echinochloa colona (L.) seeds showed lower rates of germination when exposed to contaminated medium from chromite minewaste dumps [47]. The effect of $\mathrm{Cr}$ contamination on the germination medium was also tested in mungbean (Vigna radiate L.) tolerant/sensitive cultivars and results showed that in sensitive plants, germination rate decreased in plants exposed to 96 or $192 \mu \mathrm{M} \mathrm{Cr}(\mathrm{VI})$, while in tolerant plants germination was not affected [48]. Maize seeds exposed to $\mathrm{Cr}(\mathrm{VI})$ also presented decreased rates of germination when exposed to concentrations of 100 $300 \mathrm{mg} \mathrm{L}^{-1}$ of $\mathrm{Cr}(\mathrm{VI})$ [49]. Zeid [50] found that germination of beans (Phaseolus vulgaris) was reduced in the presence of $5 \times 10^{-2} \mathrm{M} \mathrm{Cr}(\mathrm{III})$. Similar results were found by Peralta et al. [45] in alfalfa seeds exposed to $\mathrm{Cr}(\mathrm{VI})$. In another study Scoccianti and coworkers [32] found that $\mathrm{Cr}(\mathrm{III})$ at concentrations of 0.01 to $10 \mathrm{mM}$ inhibited germination of celery seeds; indeed at $10 \mathrm{mM}$ a total inhibition was detected.

In spite of the findings above, Corradi et al. [51] suggested that $\mathrm{Cr}(\mathrm{VI})$ treatment may not affect seed germination, but instead inhibit radicles growth when they emerge and contact $\mathrm{Cr}$ solution. Nevertheless, decrease in germination is a common response upon exposure to heavy metals, such as $\mathrm{Cd}, \mathrm{Pb}$, and $\mathrm{Hg}$ [52-54]. This response of low levels of germination upon $\mathrm{Cr}$ exposure can be related with decrease in $\alpha$ and $\beta$ amylase activities under Cr stress [50]. Amylase hydrolysis of starch is essential for sugar supply to developing embryos. Decrease in amylase activity under $\mathrm{Cr}$ treatment decreases sugar availability to developing embryo which may contribute to inhibition of seed germination [46].

3.4.2. Root Growth. Besides germination, also root growth is frequently affected by heavy metals. Peralta and coworkers [45] showed that $5 \mathrm{mg} \mathrm{L}^{-1}$ of $\mathrm{Cr}(\mathrm{VI})$ increased root growth comparatively to the control, and at higher doses (20 and $40 \mathrm{mg} \mathrm{L}^{-1}$ ) there was a dose-inhibition effect. $\mathrm{Cr}(\mathrm{VI})$ in concentrations up to $200 \mathrm{mg} \mathrm{L}^{-1}$ decreased growth of paddy (Oriza sativa L.) [26]. Sensitive mungbean cultivars also showed decreased root growth when exposed to $\mathrm{Cr}(\mathrm{VI})$ [55]. Samantary [48] found that there was no root elongation in mungbean exposed to $\mathrm{Cr}(\mathrm{VI})$ concentrations between 96 and $1928 \mu \mathrm{M}$, but in lower concentrations, sensitive cultivars showed root elongation similar to the control. Also, development of lateral roots and root number was also affected by $\mathrm{Cr}$ exposure [48]. Moreover, roots of Zea mays L. treated with $\mathrm{Cr}(\mathrm{VI})$ were shorter and brownish and presented less 
number of roots hairs [56]. López-Luna et al. [17] found that root growth of oat and sorghum was decreased by $\mathrm{Cr}$ concentrations in the soil of $100 \mathrm{mg} \mathrm{Cr}(\mathrm{VI}) \mathrm{kg}^{-1}$ soil [17]. Decrease in root growth in presence of $\mathrm{Cr}(\mathrm{VI})$ can be explained by inhibition of root cell division and/or elongation, which might have occurred as a result of tissue collapse and consequent incapacity of the roots to absorb water and nutrients from the medium [57] combined with extension of cell cycle [26]. Reduced root surface in $\mathrm{Cr}(\mathrm{VI})$ stressed plants may contribute to decreased capacity of plants to search for water in the soil contributing to water stress. Despite of these results, stimulation of growth under low concentrations of chromium was also described (e.g., [58]). For example, Peralta et al. [45] found that roots of alfalfa plants exposed to $5 \mathrm{mg} \mathrm{L}^{-1}$ of $\mathrm{Cr}(\mathrm{VI})$ grew $166 \%$ more than the controls.

3.4.3. Stem Growth. Stem growth is another parameter usually affected by $\mathrm{Cr}$ exposure. Mallick and coworkers [56] found that shoot length of Zea mays L. decreased significantly at $9 \mu \mathrm{g} \mathrm{mL}{ }^{-1} \mathrm{Cr}(\mathrm{VI})$ after 7 days. Also, Rout and coworkers [47] found reduction of plant height and shoot growth due to $\mathrm{Cr}$ exposure in sensitive mungbean plants. In T. aestivum L. seedlings exposed to $100 \mathrm{mg} \mathrm{L}^{-1}$ of $\mathrm{Cr}(\mathrm{VI})$ for 7 days, Dey and coworkers [46] found decrease in root length by $63 \%$ and in shoot length by $44 \%$, comparatively to the control. Concentrations of $\mathrm{Cr}(\mathrm{VI})$ in soil of $500 \mathrm{mg} \mathrm{kg}^{-1}$ also affected shoot growth of wheat and oat [17]. This decrease in plant height could be due to the reduced root growth and consequent decreased nutrients and water transport to the higher parts of the plant. Moreover, $\mathrm{Cr}$ transport to the aerial part of the plant can directly impact cellular metabolism of shoots contributing to the reduction in plant height.

3.4.4. Leaf Growth. Cauliflower grown on sand with $0.5 \mathrm{mM}$ $\mathrm{Cr}$ (III) showed suppression of growth and leaves were smaller, chlorotic, and wilted comparatively to the control [34]. Leaf area is also usually decreased in response to increase of Cr concentration $[53,59]$. Reduction of leaf area can be a consequence of reduction of the number of cells in the leaves stunted by salinization or reduction in cell size [60]. Watermelon plants growing in the presence of $\mathrm{Cr}(\mathrm{VI})$ showed reduced number and size of leaves and turned yellow, wilted, and due to loss of turgor hung down from petioles [61]. With continued Cr supply the lamina of affected old leaves became necrotic, permanently wilted, dry, and shed [61].

3.4.5. Yield. Plant yield is dependent on leaf growth, leaf area, and number. As $\mathrm{Cr}$ affects most of the biochemical and physiological process in plants, productivity and yield are also affected. $\mathrm{Cr}(\mathrm{VI})$ in irrigation water decreased significantly grain weight and yield $\left(\mathrm{kg} \mathrm{ha}^{-1}\right.$ ) of paddy (Oriza sativa) up to $80 \%$ under $200 \mathrm{mg} \mathrm{L}^{-1}$ of $\mathrm{Cr}$ [26].

\subsection{Physiological Processes}

3.5.1. Photosynthesis. As other heavy metals, Cr may affect plant photosynthesis leading to decrease in productivity and ultimately to death. In a recent work, Rodriguez and coworkers [62] showed that exposure to $\mathrm{Cr}(\mathrm{VI})$ induced a reduction of both chloroplast autofluorescence and volume in pea plants. Moreover, both $\mathrm{Cr}(\mathrm{III})$ and $\mathrm{Cr}(\mathrm{VI})$ can cause ultrastructural changes in the chloroplasts leading to inhibition of photosynthesis [63].

Respecting to pigments, Samantary [48] found chlorophyll degradation in mungbean sensitive cultivars exposed to $\mathrm{Cr}(\mathrm{VI})$ and decrease in chlorophyll a and chlorophyll b contents. Furthermore, pea plants grown in sand under different concentrations of $\mathrm{Cr}(\mathrm{VI})$ presented reduced chlorophyll contents in leaves [27]. Dey and coworkers [46] also found that total chlorophyll content decreased in shoots of T. aestivum L. with increasing $\mathrm{Cr}(\mathrm{VI})$ concentration. Concerning $\mathrm{Cr}(\mathrm{III})$, Chatterjee and Chatterjee found a decrease in chlorophyll contents in cauliflower grown on sand with $0.5 \mathrm{mM}$ of $\mathrm{Cr}$ (III) [34]. Also, in celery seedlings, $\mathrm{Cr}$ (III) reduced chlorophyll contents mostly at concentrations of $1 \mathrm{mM}$ [64].

When comparing the effects of $\mathrm{Cr}(\mathrm{III})$ and $\mathrm{Cr}(\mathrm{VI})$ on photosynthesis parameters of water hyacinth, Paiva and coworkers [12] found that $\mathrm{Cr}(\mathrm{III})$ was much less toxic than $\mathrm{Cr}(\mathrm{VI})$, and might eventually increase photosynthesis and chlorophyll content. In another study, Zeid [50] found that low and moderate concentrations of $\mathrm{Cr}$ (III) $\left(10^{-6}\right.$ and $10^{-4} \mathrm{M}$ ) in irrigation solution increased pigment content in leaves, but higher $\mathrm{Cr}(\mathrm{III})$ concentrations $\left(10^{-2} \mathrm{M}\right)$ reduced the contents of chlorophyll a, chlorophyll b, and carotenoids.

This general profile of decrease in chlorophyll content at high $\mathrm{Cr}$ concentrations suggests that chlorophyll synthesis and/or chlorophyllase activity is being affected. Vajpayee and coworkers [65] showed that $\mathrm{Cr}$ affects pigment biosynthesis by, for instance, degrading $\delta$-aminolaevulinic acid dehydrates, an essential enzyme in chlorophyll biosynthesis. Vernay and coworkers [30] also presented evidence that $\mathrm{Cr}$ competes with $\mathrm{Mg}$ and $\mathrm{Fe}$ for assimilation and transport to leaves, affecting therefore pigment biosynthesis. As the levels of reactive oxygen species (ROS) usually increase as a result of $\mathrm{Cr}$ exposure (e.g., $[63,66])$, Juarez and coworkers [67] showed that ROS damages pigment-protein complexes located in thylakoid membranes followed by pheophitinization of chlorophylls (substitution of $\mathrm{Mg}^{2+}$ by $\mathrm{H}^{+}$ions) and destruction of thylakoid membranes.

Considering the effects of $\mathrm{Cr}$ on plant fluorescence parameters, Liu and coworkers [29] found that A. viridis L. exposure to $\mathrm{Cr}(\mathrm{VI})$ resulted in decreased net photosynthetic rate, transpiration rate, stomatal conductance, and intercellular $\mathrm{CO}_{2}$ concentration. Also, chlorophyll fluorescence parameters $F_{v} / F_{m}, F_{v}^{\prime} / F_{m}^{\prime}$, $\Phi$ PSII, and $q_{p}$, decreased in $\operatorname{Cr}(\mathrm{VI})$ treated, but $q_{N}$ and NPQ showed an increase in $\mathrm{Cr}(\mathrm{VI})$ treated plants [29], indicating that the photochemical apparatus might have been compromised. In another study, Vernay and coworkers [30] found that $\mathrm{Cr}(\mathrm{VI})$ affected $L$. perenne fluorescence parameters associated with PSII. In another study, these authors compared the effects of $\mathrm{Cr}(\mathrm{VI})$ and $\mathrm{Cr}(\mathrm{III})$ on Datura innoxia and found that $\mathrm{Cr}(\mathrm{VI})$ had a more toxic effect on those plants than $\mathrm{Cr}$ (III) [68]. In plants stressed with $\mathrm{Cr}(\mathrm{VI})$, a decrease in the quantum yield of PSII electron transport (ФPSII), $F_{v}^{\prime} / F_{m}^{\prime}$ and $q_{p}$ was observed [68]. ФPSII represents the number of electrons transported across a PSII reaction center per mole of quantum absorbed 
by PSII, $F_{v}^{\prime} / F_{m}^{\prime}$ represents the excitation capture efficiency of open PSII reaction centers, while $\left(q_{p}\right)$ reflects the number of open reaction centers and it is an indicator of the capacity of photochemical processes [69].

3.5.2. Mineral Nutrition. Cr, being structurally similar to other essential elements, may affect plant mineral nutrition. Mallick et al. [56] found that $\mathrm{Cr}$ exposure decreased $\mathrm{Cu}$ absorption in Zea mays roots, while leaves were not affected. Uptake of both macronutrients (e.g., N, P, K) and micronutrients decreased with increase of $\mathrm{Cr}(\mathrm{VI})$ in irrigation of paddy [26]. Also, decreased uptake of the micronutrients $\mathrm{Mn}, \mathrm{Fe}, \mathrm{Cu}$, and $\mathrm{Zn}$ was detected by Liu et al. [29] in A. viridis $\mathrm{L}$. exposed to $\mathrm{Cr}(\mathrm{VI})$. High content of $\mathrm{Cr}$ may displace the nutrients from physiological binding sites and consequently decrease uptake and translocation of essential elements. In watermelon plants grown in the presence of $\mathrm{Cr}$, an increase in concentrations of $\mathrm{P}$ and $\mathrm{Mn}$ and decrease in $\mathrm{Fe}, \mathrm{Cu}, \mathrm{Zn}$, and $\mathrm{S}$ contents in leaves was observed [61]. In L. perenne, Vernay and coworkers [30] found that $\mathrm{Cr}(\mathrm{VI})$ exposure affected mineral contents mostly $\mathrm{Fe}, \mathrm{Ca}$, and $\mathrm{Mg}$. $\mathrm{Cr}(\mathrm{VI})$ also decreased Fe concentration in spinach [31] and sunflower [70]. The decrease in Fe concentration in leaf tissue in response to $\mathrm{Cr}$ toxicity is suggestive of $\mathrm{Cr}(\mathrm{VI})$ interference in the availability of Fe, leading to impairment of Fe metabolism [71].

3.5.3. Enzymes and Other Compounds. The activity of antioxidant enzymes, namely, peroxidase, catalase (CAT), glucose-6-phosphate dehydrogenase and superoxide dismutase (SOD) increased in case of Cr-sensitive of mungbean exposed to different $\mathrm{Cr}$ concentrations. However, the level of antioxidant enzymes decreased in Cr-tolerant cultivars [48]. SOD and CAT activities decreased in T. aestivum L. grown in the presence of $\mathrm{K}_{2} \mathrm{Cr}_{2} \mathrm{O}_{7}$ in roots and shoots [46]. CAT activity also decreased in A. viridis L. exposed to $\mathrm{Cr}(\mathrm{VI})$ but an increase in SOD and guaiacol peroxidase (POX) activity was observed with increase of $\mathrm{Cr}(\mathrm{VI})$ concentration [29]. POX decreased in roots and increased in shoots of $T$. aestivum exposed to $\mathrm{Cr}(\mathrm{VI})$ [46]. Prado et al. [72] evaluated the metabolic responses to $\mathrm{Cr}(\mathrm{VI})$ exposure in floating and submerged leaves of Salvinia minima plants and found that $\mathrm{Cr}$ affected sucrose contents which were higher in Cr-treated leaves, while glucose contents showed an inverse pattern. Invertase activity also was also affected and suffered a decrease in floating leaves [72]. Zaimoglu and coworkers [73] studied the antioxidant responses of Brassica juncea and Brassica oleracea to soils enriched with $\mathrm{Cr}(\mathrm{VI})$ and found that total enzymatic activity was higher in B. oleracea than in B. juncea. $\mathrm{Cr}(\mathrm{VI})$ and also a decrease in CAT activity in both species [73]. Cellular antioxidants play an important role in protecting Brassica sp. to Cr-induced oxidative stress. This high activity of antioxidant enzymes and consequent detoxification of ROS contributes to relative tolerance of these species to $\mathrm{Cr}(\mathrm{VI})$. Furthermore, Guédard and coworkers [74] found that leaf fatty acid composition of Lactuca serriola was affected by the presence of $\mathrm{Cr}$ in metallurgic landfill soil.
3.6. Genotoxicity. Zou and coworkers [58] evaluated the effects of $\mathrm{Cr}(\mathrm{VI})$ on root cell growth and division of root tips of $A$. viridis $\mathrm{L}$. and found that the mitotic index decreased with increased concentration of $\mathrm{Cr}(\mathrm{VI})$. Furthermore, $\mathrm{Cr}(\mathrm{VI})$ also affected chromosome morphology with increase in the frequency of c-mitosis, chromosome bridges, anaphase bridges, and chromosome stickiness [58].

Pea plants grown in the presence of $\mathrm{Cr}(\mathrm{VI})$ showed significant variations on cell cycle dynamics and ploidy level in leaves; however roots presented a cell cycle arrest at G2/M phase of the cell cycle; also polyploidization at both 2C and 4C levels was detected [75]. Moreover, in leaves and roots, an increase in DNA damage, assessed both by comet assay, and an increase in full peak coefficient of variation (FPCV) of G0/G1 were also detected [75]. Labra et al. [76] found hypermethylation of DNA and increase in DNA polymorphism in Brassica napus in response to $\mathrm{Cr}(\mathrm{VI})$ exposure. $\mathrm{Cr}(\mathrm{VI})$ also induced genotoxicity detected by AFLP analysis in Arabidopsis thaliana (L.) [77]. Furthermore, Knasmüller and coworkers [78] compared $\mathrm{Cr}(\mathrm{VI})$ and $\mathrm{Cr}(\mathrm{III})$ with respect to their ability to induce micronucleus in Tradescantia and found that only in $\mathrm{Cr}(\mathrm{VI})$-exposed plants there was an increases in micronucleus frequencies. Moreover, Wang [79] in a survey to assess the genotoxic effects of $\mathrm{Cr}$ in water extracted from contaminated soil found that it was able to induce micronuclei in Vicia faba roots. Furthermore, Vannini and coworkers [80] evaluated the molecular changes induced by $\mathrm{Cr}(\mathrm{III})$ and $\mathrm{Cr}(\mathrm{VI})$ on germination kiwifruit pollen and concluded that neither $\mathrm{Cr}$ species induced a genotoxic effects. Both $\mathrm{Cr}$ species induced a strong reduction of proteins involved in mitochondrial oxidative phosphorylation and a decline in ATP levels [80].

\section{Concluding Remarks}

This paper includes an overview of the literature about $\mathrm{Cr}$ toxicity in the environment, especially in water and soil and provides new insights about $\mathrm{Cr}$ toxicity in plants. $\mathrm{Cr}$ exists mainly in three oxidative states $\mathrm{Cr}(0), \mathrm{Cr}(\mathrm{III})$, and $\mathrm{Cr}(\mathrm{VI})$, which are the most stable forms of $\mathrm{Cr}$. As $\operatorname{Cr}(0)$ is the metallic form, the forms of $\mathrm{Cr}(\mathrm{III})$ and $\mathrm{Cr}(\mathrm{VI})$ are the most preponderant in soils and water. Once in water/soil, Cr suffers a variety of transformations such as oxidation, reduction, sorption, desorption, precipitation, and dissolution. While $\mathrm{Cr}$ (III) solubility is dependent on $\mathrm{pH}$, $\mathrm{Cr}(\mathrm{VI})$ is extremely soluble under all $\mathrm{pH}$ conditions. $\mathrm{Cr}$ as being a nonessential element for plants does not have any specific mechanism for its uptake. $\mathrm{Cr}$ (III) uptake is a passive process, whereas $\mathrm{Cr}(\mathrm{VI})$ uptake is performed by carriers of essential elements such as sulphate. $\mathrm{Cr}$ accumulates mainly on plant roots, being translocated to shoots in small levels, independently of $\mathrm{Cr}$ specie. Despite known toxicity of $\mathrm{Cr}$ to plants, there are several plants that hyperaccumulate this metal contributing to its removal from soil/water, showing good potential for application in $\mathrm{Cr}$ phytoremediation strategies. Cr affects several processes in plants, namely, seed germination, growth, yield and also physiological processes as photosynthesis impairment and nutrient and oxidative 
imbalances. Also, it has been shown that $\mathrm{Cr}$ is able to induce genotoxicity in several plant species.

\section{Acknowledgment}

The work of H. Oliveira was supported by FCT (Grant reference SFRH/BPD/48853/2008).

\section{References}

[1] S. Avudainayagam, M. Megharaj, G. Owens, R. S. Kookana, D. Chittleborough, and R. Naidu, "Chemistry of chromium in soils with emphasis on tannery waste sites," Reviews of Environmental Contamination and Toxicology, vol. 178, pp. 53-91, 2003.

[2] P. Babula, V. Adam, R. Opatrilova, J. Zehnalek, L. Havel, and R. Kizek, "Uncommon heavy metals, metalloids and their plant toxicity: a review," Environmental Chemistry Letters, vol. 6, no. 4, pp. 189-213, 2008.

[3] A. M. Zayed and N. Terry, "Chromium in the environment: factors affecting biological remediation," Plant and Soil, vol. 249, no. 1, pp. 139-156, 2003.

[4] T. Becquer, C. Quantin, M. Sicot, and J. P. Boudot, "Chromium availability in ultramafic soils from New Caledonia," Science of the Total Environment, vol. 301, no. 1-3, pp. 251261, 2003.

[5] J. R. Peralta-Videa, M. L. Lopez, M. Narayan, G. Saupe, and J. Gardea-Torresdey, "The biochemistry of environmental heavy metal uptake by plants: implications for the food chain," International Journal of Biochemistry and Cell Biology, vol. 41, no. 8-9, pp. 1665-1677, 2009.

[6] D. E. Kimbrough, Y. Cohen, A. M. Winer, L. Creelman, and C. Mabuni, "A critical assessment of chromium in the environment," Critical Reviews in Environmental Science and Technology, vol. 29, no. 1, pp. 1-46, 1999.

[7] International Agency for Research on Cancer, "Chromium, nickel and welding," in IARC Monographs on the Evaluation of Carcinogenic Risks to Humans, vol. 49, The International Agency for Research on Cancer, Scientific Publications, Lyon , France, 1990.

[8] A. K. Shanker, C. Cervantes, H. Loza-Tavera, and S. Avudainayagam, "Chromium toxicity in plants," Environment International, vol. 31, no. 5, pp. 739-753, 2005.

[9] V. Velma, S. S. Vutukuru, and P. B. Tchounwou, "Ecotoxicology of hexavalent chromium in freshwater fish: a critical review," Reviews on Environmental Health, vol. 24, no. 2, pp. 129-145, 2009.

[10] F. L. Petrilli and S. De Flora, "Toxicity and mutagenicity of hexavalent chromium on Salmonella typhimurium," Applied and Environmental Microbiology, vol. 33, no. 4, pp. 805-809, 1977.

[11] Agency for Toxic Substances and Disease Registry, Toxicological Profile for Chromium, Health Administration Press, Atlanta, Ga, USA, 2000.

[12] L. B. Paiva, J. G. de Oliveira, R. A. Azevedo, D. R. Ribeiro, M. G. da Silva, and A. P. Vitória, "Ecophysiological responses of water hyacinth exposed to $\mathrm{Cr}^{3+}$ and $\mathrm{Cr}^{6+}$," Environmental and Experimental Botany, vol. 65, no. 2-3, pp. 403-409, 2009.

[13] Chandra P., Sinha S., and Rai U. N., "Bioremediation of Cr from water and soil by vascular aquatic plants," in Phytoremediation of Soil and Water Contaminants, Kruger E. L., Anderson T. A., and Coats J. R., Eds., vol. 664 of ACS Symposium, pp.
274-282, DC7 American Chemical Society, Washington, DC, USA, 1997.

[14] I. Rosas, R. Belmomt, A. Baez, and R. Villalobos-Pietrini, "Some aspects of the environmental exposure to chromium residues in Mexico," Water, Air, and Soil Pollution, vol. 48, no. 3-4, pp. 463-475, 1989.

[15] S. E. Fendorf and R. J. Zasoski, "Chromium(III) oxidation by $\delta-\mathrm{MnO}_{2}$. 1. Characterization," Environmental Science and Technology, vol. 26, no. 1, pp. 79-85, 1992.

[16] E. E. Cary, "Chromium in air, soils, and natural waters," in Biological and Environmental Aspects of Chromium, S. Langard, Ed., pp. 49-63, Elsevier Biomedical, New York, NY, USA, 1982.

[17] J. López-Luna, M. C. González-Chávez, F. J. Esparza-García, and R. Rodríguez-Vázquez, "Toxicity assessment of soil amended with tannery sludge, trivalent chromium and hexavalent chromium, using wheat, oat and sorghum plants," Journal of Hazardous Materials, vol. 163, no. 2-3, pp. 829-834, 2009.

[18] R. A. Skeffington, P. R. Shewry, and P. J. Peterson, "Chromium uptake and transport in barley seedlings (Hordeum vulgare L.)," Planta, vol. 132, no. 3, pp. 209-214, 1976.

[19] Y. J. Kim, J. H. Kim, C. E. Lee et al., "Expression of yeast transcriptional activator MSN1 promotes accumulation of chromium and sulfur by enhancing sulfate transporter level in plants," FEBS Letters, vol. 580, no. 1, pp. 206-210, 2006.

[20] C. Cervantes, J. C. García, S. Devars et al., "Interactions of chromium with microorganisms and plants," FEMS Microbiology Reviews, vol. 25, no. 3, pp. 335-347, 2001.

[21] V. Ramachandran, T. J. D’Souza, and K. B. Mistry, "Uptake and transport of chromium in plants," Journal of Nuclear Agriculture and Biology, vol. 9, no. 4, pp. 126-128, 1980.

[22] A. Zayed, C. M. Lytle, J. H. Qian, and N. Terry, "Chromium accumulation, translocation and chemical speciation in vegetable crops," Planta, vol. 206, no. 2, pp. 293-299, 1998.

[23] S. Mishra, V. Singh, S. Srivastava et al., "Studies on uptake of trivalent and hexavalent chromium by maize (Zea mays)," Food and Chemical Toxicology, vol. 33, no. 5, pp. 393-397, 1995.

[24] L. R. Hossner, "Phytoaccumulation of selected heavy metals, uranium, and plutonium in plant systems," Quarterly Progress Report, Texas A\&M University: College Station, TX, Project UTA96-0043, 1996.

[25] J. J. Mortvedt and P. M. Giordano, "Response of corn to zinc and chromium in municipal wastes applied to soil," Journal of Environmental Quality, vol. 4, no. 2, pp. 170-174, 1975.

[26] P. Sundaramoorthy, A. Chidambaram, K. S. Ganesh, P. Unnikannan, and L. Baskaran, "Chromium stress in paddy: (i) nutrient status of paddy under chromium stress; (ii) phytoremediation of chromium by aquatic and terrestrial weeds," Comptes Rendus Biologies, vol. 333, no. 8, pp. 597-607, 2010.

[27] K. K. Tiwari, S. Dwivedi, N. K. Singh, U. N. Rai, and R. D. Tripathi, "Chromium (VI) induced phytotoxicity and oxidative stress in pea (Pisum sativum L.): biochemical changes and translocation of essential nutrients," Journal of Environmental Biology, vol. 30, no. 3, pp. 389-394, 2009.

[28] E. W. Huffman Jr. and H. W. Allaway, "Chromium in plants: distribution in tissues, organelles, and extracts and availability of bean leaf Cr to animals," Journal of Agricultural and Food Chemistry, vol. 21, no. 6, pp. 982-986, 1973.

[29] D. Liu, J. Zou, M. Wang, and W. Jiang, "Hexavalent chromium uptake and its effects on mineral uptake, antioxidant defence system and photosynthesis in Amaranthus viridis L.," Bioresource Technology, vol. 99, no. 7, pp. 2628-2636, 2008. 
[30] P. Vernay, C. Gauthier-Moussard, and A. Hitmi, "Interaction of bioaccumulation of heavy metal chromium with water relation, mineral nutrition and photosynthesis in developed leaves of Lolium perenne L.," Chemosphere, vol. 68, no. 8, pp. 1563-1575, 2007.

[31] R. Gopal, A. H. Rizvi, and N. Nautiyal, "Chromium alters iron nutrition and water relations of spinach," Journal of Plant Nutrition, vol. 32, no. 9, pp. 1551-1559, 2009.

[32] V. Scoccianti, R. Crinelli, B. Tirillini, V. Mancinelli, and A. Speranza, "Uptake and toxicity of Cr(III) in celery seedlings," Chemosphere, vol. 64, no. 10, pp. 1695-1703, 2006.

[33] A. Zayed, C. M. Lytle, J. H. Qian, and N. Terry, "Chromium accumulation, translocation and chemical speciation in vegetable crops," Planta, vol. 206, no. 2, pp. 293-299, 1998.

[34] J. Chatterjee and C. Chatterjee, "Phytotoxicity of cobalt, chromium and copper in cauliflower," Environmental Pollution, vol. 109, no. 1, pp. 69-74, 2000.

[35] S. Bluskov, J. M. Arocena, O. O. Omotoso, and J. P. Young, "Uptake, distribution, and speciation of chromium in Brassica Juncea," International Journal of Phytoremediation, vol. 7, no. 2, pp. 153-165, 2005.

[36] I. D. Pulford, C. Watson, and S. D. McGregor, "Uptake of chromium by trees: prospects for phytoremediation," Environmental Geochemistry and Health, vol. 23, no. 3, pp. 307$311,2001$.

[37] M. Rafati, N. Khorasani, F. Moattar, A. Shirvany, F. Moraghebi, and S. Hosseinzadeh, "Phytoremediation potential of Populus alba and Morus alba for cadmium, chromuim and nickel absorption from polluted soil," International Journal of Environmental Research, vol. 5, no. 4, pp. 961-970, 2011.

[38] M. Gafoori, N. M. Majid, M. M. Islam, and S. Luhat, "Bioaccumulation of heavy metals by Dyera costulata cultivated in sewage sludge contaminated soil," African Journal of Biotechnology, vol. 10, no. 52, pp. 10674-10682, 2011.

[39] P. Sampanpanish, W. Pongsapich, S. Khaodhiar, and E. Khan, "Chromium removal from soil by phytoremediation with weed plant species in Thailand," Water, Air, and Soil Pollution, vol. 6, no. 1-2, pp. 191-206, 2006.

[40] J. J. Mellem, H. Baijnath, and B. Odhav, "Bioaccumulation of $\mathrm{Cr}, \mathrm{Hg}, \mathrm{As}, \mathrm{Pb}, \mathrm{Cu}$ and $\mathrm{Ni}$ with the ability for hyperaccumulation by Amaranthus dubius," African Journal of Agricultural Research, vol. 7, no. 4, pp. 591-596, 2012.

[41] J. L. Gardea-Torresdey, J. R. Peralta-Videa, M. Montes, G. de la Rosa, and B. Corral-Diaz, "Bioaccumulation of cadmium, chromium and copper by Convolvulus arvensis L.: impact on plant growth and uptake of nutritional elements," Bioresource Technology, vol. 92, no. 3, pp. 229-235, 2004.

[42] A. Weerasinghe, S. Ariyawnasa, and R. Weerasooriya, "Phytoremediation potential of Ipomoea aquatica for $\mathrm{Cr}(\mathrm{VI})$ mitigation," Chemosphere, vol. 70, no. 3, pp. 521-524, 2008.

[43] C. Mant, S. Costa, J. Williams, and E. Tambourgi, "Phytoremediation of chromium by model constructed wetland," Bioresource Technology, vol. 97, no. 15, pp. 1767-1772, 2006.

[44] R. M. T. Barbosa, A. A. F. de Almeida, M. S. Mielke, L. L. Loguercio, P. A. O. Mangabeira, and F. P. Gomes, "A physiological analysis of Genipa americana L.: a potential phytoremediator tree for chromium polluted watersheds," Environmental and Experimental Botany, vol. 61, no. 3, pp. 264-271, 2007.

[45] J. R. Peralta, J. L. Gardea-Torresdey, K. J. Tiemann et al., "Uptake and effects of five heavy metals on seed germination and plant growth in alfalfa (Medicago sativa) L.," Bulletin of Environmental Contamination and Toxicology, vol. 66, no. 6, pp. 727-734, 2001.
[46] S. K. Dey, P. P. Jena, and S. Kundu, "Antioxidative efficiency of Triticum aestivum L. exposed to chromium stress," Journal of Environmental Biology, vol. 30, no. 4, pp. 539-544, 2009.

[47] G. R. Rout, S. Samantaray, and P. Das, "Effects of chromium and nickel on germination and growth in tolerant and non-tolerant populations of Echinochloa colona (L.) link," Chemosphere, vol. 40, no. 8, pp. 855-859, 2000.

[48] S. Samantary, "Biochemical responses of Cr-tolerant and Crsensitive mung bean cultivars grown on varying levels of chromium," Chemosphere, vol. 47, no. 10, pp. 1065-1072, 2002.

[49] M. Labra, E. Gianazza, R. Waitt et al., "Zea mays L. protein changes in response to potassium dichromate treatments," Chemosphere, vol. 62, no. 8, pp. 1234-1244, 2006.

[50] I. M. Zeid, "Responses of Phaseolus vulgaris to chromium and cobalt treatments," Biologia Plantarum, vol. 44, no. 1, pp. 111115, 2001.

[51] M. G. Corradi, A. Bianchi, and A. Albasini, "Chromium toxicity in Salvia sclarea. I. Effects of hexavalent chromium on seed germination and seedling development," Environmental and Experimental Botany, vol. 33, no. 3, pp. 405-413, 1993.

[52] M. Smiri, A. Chaoui, and E. El Ferjani, "Respiratory metabolism in the embryonic axis of germinating pea seed exposed to cadmium," Journal of Plant Physiology, vol. 166, no. 3, pp. 259-269, 2009.

[53] S. Pandey, K. Gupta, and A. K. Mukherjee, "Impact of cadmium and lead on Catharanthus roseus - a phytoremediation study," Journal of Environmental Biology, vol. 28, no. 3, pp. 655-662, 2007.

[54] O. Munzuroglu and H. Geckil, "Effects of metals on seed germination, root elongation, and coleoptile and hypocotyl growth in Triticum aestivum and Cucumis sativus," Archives of Environmental Contamination and Toxicology, vol. 43, no. 2, pp. 203-213, 2002.

[55] G. R. Rout, S. Samantaray, and P. Das, "Differential chromium tolerance among eight mungbean cultivars grown in nutrient culture," Journal of Plant Nutrition, vol. 20, no. 4-5, pp. 473483, 1997.

[56] S. Mallick, G. Sinam, R. Kumar Mishra, and S. Sinha, "Interactive effects of $\mathrm{Cr}$ and $\mathrm{Fe}$ treatments on plants growth, nutrition and oxidative status in Zea mays L.," Ecotoxicology and Environmental Safety, vol. 73, no. 5, pp. 987-995, 2010.

[57] J. Barceló, C. Poschenrieder, and J. Gunsé, "Effect of chromium (VI) on mineral element composition of bush beans," Journal of Plant Nutrition, vol. 8, pp. 211-217, 1985.

[58] J. H. Zou, M. Wang, W. S. Jiang, and D. H. Liu, "Effects of hexavalent chromium (VI) on root growth and cell division in root tip cells of Amaranthus viridis L.," Pakistan Journal of Botany, vol. 38, no. 3, pp. 673-681, 2006.

[59] V. Pandey, V. Dixit, and R. Shyam, "Chromium effect on ROS generation and detoxification in pea (Pisum sativum) leaf chloroplasts," Protoplasma, vol. 236, no. 1-4, pp. 85-95, 2009.

[60] R. H. Nieman, "Expansion of bean leaves and its suppression by salinity," Plant Physiology, vol. 40, pp. 156-161, 1965.

[61] B. K. Dube, K. Tewari, J. Chatterjee, and C. Chatterjee, "Excess chromium alters uptake and translocation of certain nutrients in citrullus," Chemosphere, vol. 53, no. 9, pp. 1147-1153, 2003.

[62] E. Rodriguez, C. Santos, R. Azevedo, J. Moutinho-Pereira, C. Correia, and M. C. Dias, "Chromium (VI) induces toxicity at different photosynthetic levels in pea," Plant Physiology and Biochemistry, vol. 53, pp. 94-100, 2012.

[63] S. K. Panda and S. Choudhury, "Chromium stress in plants," Brazilian Journal of Plant Physiology, vol. 17, no. 1, pp. 95-102, 2005. 
[64] V. Scoccianti, R. Crinelli, B. Tirillini, V. Mancinelli, and A. Speranza, "Uptake and toxicity of Cr(III) in celery seedlings," Chemosphere, vol. 64, no. 10, pp. 1695-1703, 2006.

[65] P. Vajpayee, S. C. Sharma, R. D. Tripathi, U. N. Rai, and M. Yunus, "Bioaccumulation of chromium and toxicity to photosynthetic pigments, nitrate reductase activity and protein content of Nelumbo nucifera Gaertn," Chemosphere, vol. 39, no. 12, pp. 2159-2169, 1999.

[66] V. Pandey, V. Dixit, and R. Shyam, "Chromium effect on ROS generation and detoxification in pea (Pisum sativum) leaf chloroplasts," Protoplasma, vol. 236, no. 1-4, pp. 85-95, 2009.

[67] A. B. Juarez, L. Barsanti, V. Passarelli et al., "In vivo microspectroscopy monitoring of chromium effects on the photosynthetic and photoreceptive apparatus of Eudorina unicocca and Chlorella kessleri," Journal of Environmental Monitoring, vol. 10, no. 11, pp. 1313-1318, 2008.

[68] P. Vernay, C. Gauthier-Moussard, L. Jean et al., "Effect of chromium species on phytochemical and physiological parameters in Datura innoxia," Chemosphere, vol. 72, no. 5, pp. 763-771, 2008.

[69] K. Maxwell and G. N. Johnson, "Chlorophyll fluorescence-a practical guide," Journal of Experimental Botany, vol. 51, no. 345, pp. 659-668, 2000.

[70] R. Gupta, R. Mehta, N. Kumar, and D. S. Dahiya, "Effect of chromium (VI) on phosphorus fractions in developing sunflower seeds," Crop Research, vol. 20, pp. 46-51, 2000.

[71] R. Gopal, A. H. Rizvi, and N. Nautiyal, "Chromium alters iron nutrition and water relations of Spinach," Journal of Plant Nutrition, vol. 32, no. 9, pp. 1551-1559, 2009.

[72] C. Prado, L. Rodríguez-Montelongo, J. A. González, E. A. Pagano, M. Hilal, and F. E. Prado, "Uptake of chromium by Salvinia minima: effect on plant growth, leaf respiration and carbohydrate metabolism," Journal of Hazardous Materials, vol. 177, no. 1-3, pp. 546-553, 2010.

[73] Z. Zaimoglu, N. Koksal, N. Basci, M. Kesici, H. Gulen, and F. Budak, "Antioxidative enzyme activities in Brassica juncea L. and Brassica oleracea L. plants under chromium stress," International Journal of Food, Agriculture \& Environment, vol. 9, no. 1, pp. 676-679, 2011.

[74] M. Le Guédard, O. Faure, and J. J. Bessoule, "Soundness of in situ lipid biomarker analysis: early effect of heavy metals on leaf fatty acid composition of Lactuca serriola," Environmental and Experimental Botany, vol. 76, pp. 54-59, 2012.

[75] E. Rodriguez, R. Azevedo, P. Fernandes, and C. Santos, "Cr(VI) induces DNA damage, cell cycle arrest and polyploidization: a flow cytometric and comet assay study in Pisum sativum," Chemical Research in Toxicology, vol. 24, no. 7, pp. 1040-1047, 2011.

[76] M. Labra, F. Grassi, S. Imazio et al., "Genetic and DNA-methylation changes induced by potassium dichromate in Brassica napus L.," Chemosphere, vol. 54, no. 8, pp. 1049-1058, 2004.

[77] M. Labra, T. Di Fabio, F. Grassi et al., "AFLP analysis as biomarker of exposure to organic and inorganic genotoxic substances in plants," Chemosphere, vol. 52, no. 7, pp. 11831188, 2003.

[78] S. Knasmüller, E. Gottmann, H. Steinkellner et al., "Detection of genotoxic effects of heavy metal contaminated soils with plant bioassays," Mutation Research, vol. 420, no. 1-3, pp. 3748, 1998.

[79] H. Wang, "Clastogenicity of chromium contaminated soil samples evaluated by Vicia root-micronucleus assay," Mutation Research, vol. 426, no. 2, pp. 147-149, 1999.

[80] C. Vannini, G. Domingo, M. Marsoni et al., "Proteomic changes and molecular effects associated with $\mathrm{Cr}(\mathrm{III})$ and
$\mathrm{Cr}(\mathrm{VI})$ treatments on germinating kiwifruit pollen," Phytochemistry, vol. 72, no. 14-15, pp. 1786-1795, 2011. 

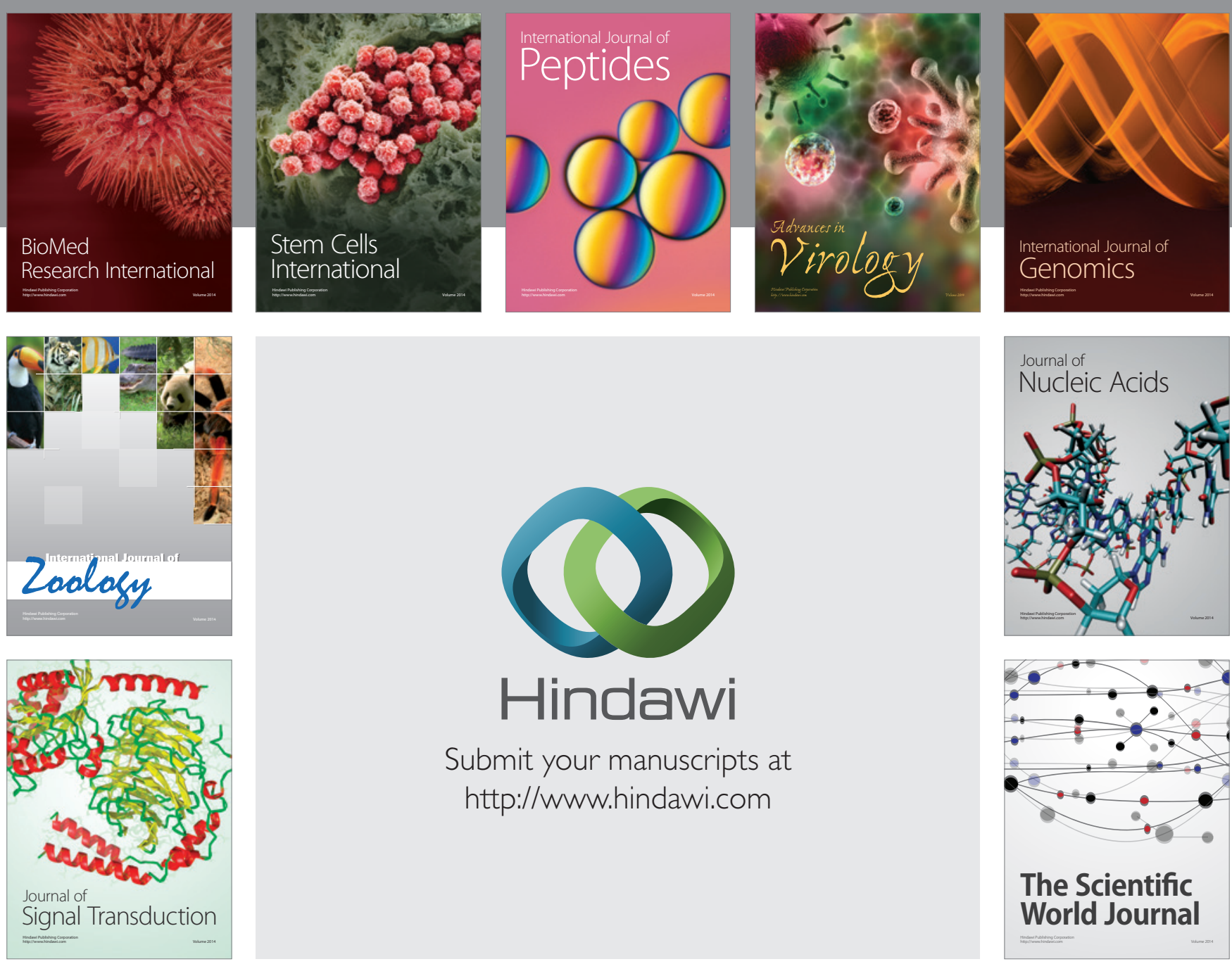

Submit your manuscripts at

http://www.hindawi.com
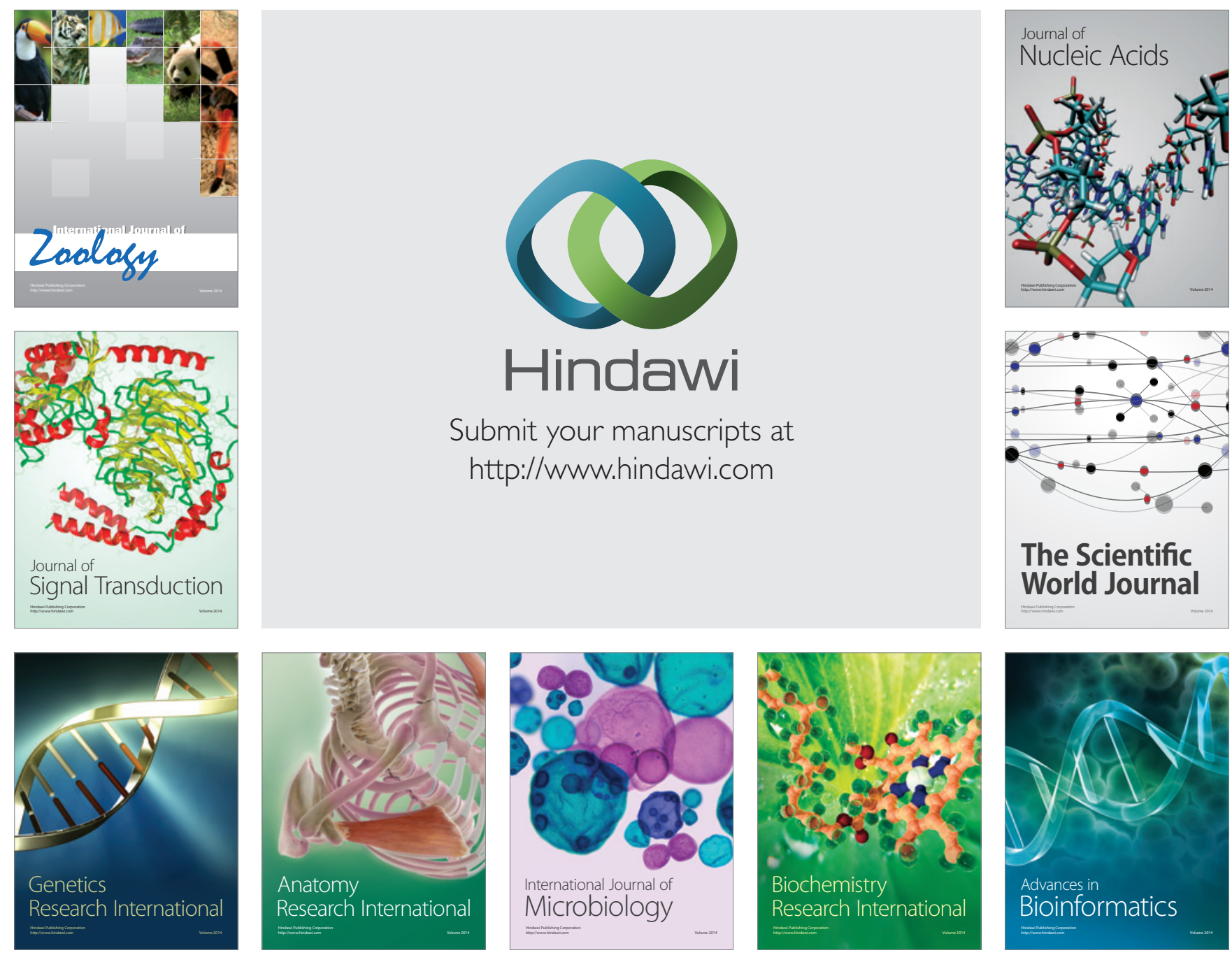

The Scientific World Journal
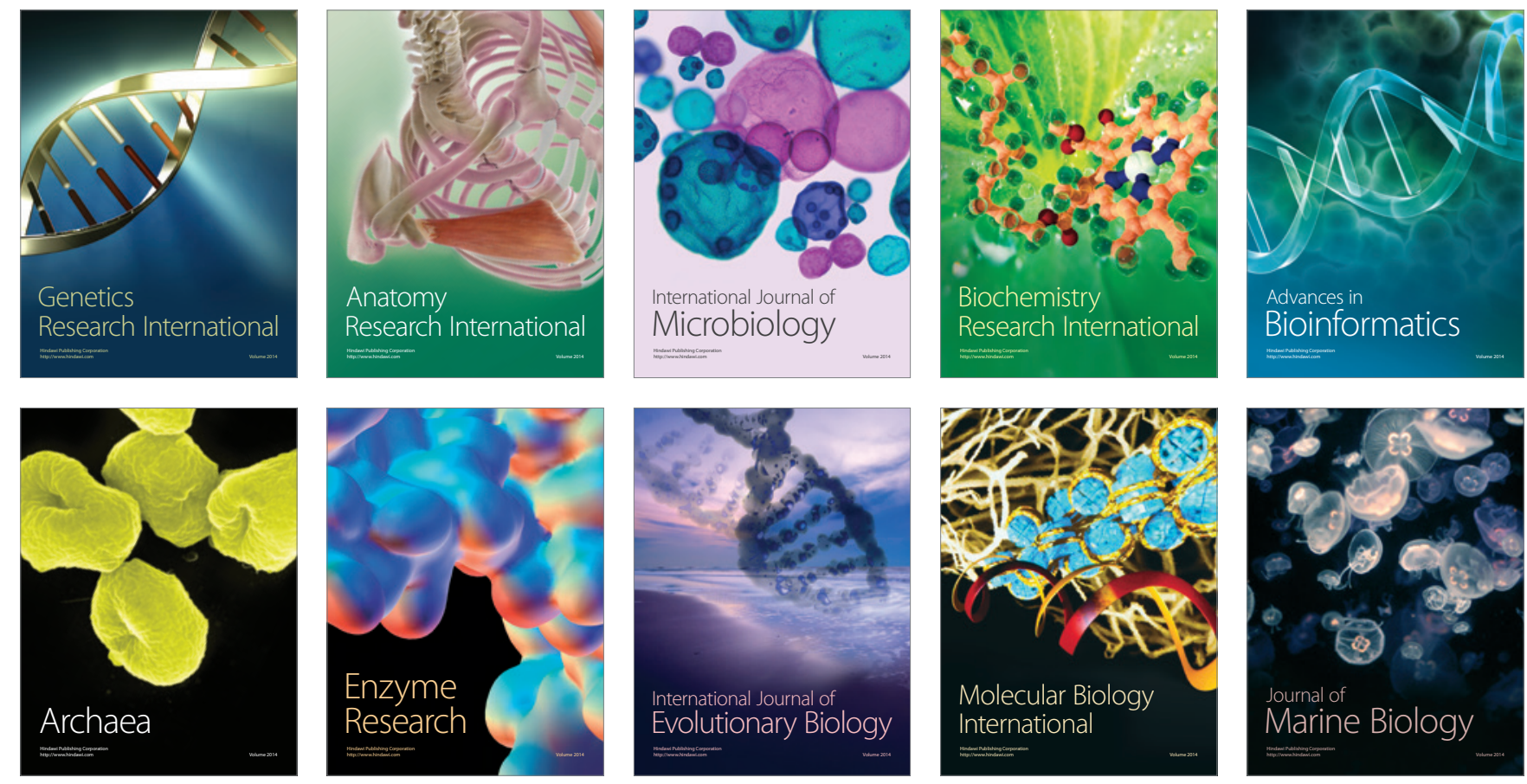